\title{
KESULITAN SISWA SMP KELAS VIII DALAM MENYELESAIKAN SOAL SISTEM PERSAMAAN LINIER DUA VARIABEL (SPLDV)
}

\author{
Siti Rohmah Paujiah¹, Luvy Sylviana Zanthy² \\ 1,2 Institut Keguruan dan IImu Pendidikan (IKIP) Siliwangi, Jl. Terusan Jend. Sudirman, Cimahi, Indonesia \\ Email: paujiah94@gmail.com
}

\begin{abstract}
This research aims to find out the difficulty of junior high school students in solving the problem of the Two-Variable Linear Equation System (SPLDV). The subjects of this study were 13 grade VIII students from one of the private junior high schools in Cianjur Regency. The instrument used in this study is a question of a description consisting of 5 questions. Data collection also comes with interviews on subjects to track the difficulty in completing a given test. The results showed that the difficulties experienced by students in solving SPLDV material problems were difficulty in using the properties of improvement and multiplication in the equation, difficulty determining the symbols that makeup SPLDV, difficulty determining the final result, and difficulty in performing operations on numbers. The factors that cause these difficulties are the rush to answer questions, lack of scrutiny, forget formulas, not understand the problem, and misoperate. Based on the results of the analysis, the average percentage of the overall question given that students are relatively low.
\end{abstract}

Keywords: Mathematical concepts, student difficulty, two-variable linear equation system

\section{ABSTRAK}

Penelitian ini bertujuan untuk mengetahui kesulitan siswa SMP dalam menyelesaikan soal Sistem Persamaan Linier Dua Variabel (SPLDV). Subjek dari penelitian ini adalah 13 orang siswa kelas VIII salah satu SMP swasta di Kabupaten Cianjur. Instrumen yang digunakan dalam penelitian ini berupa soal uraian yang terdiri dari 5 butir soal. Pengumpulan data juga dilengkapi dengan wawancara terhadap subjek untuk melacak kesulitan dalam menyelesaikan tes yang diberikan. Hasil penelitian menunjukkan bahwa kesulitan yang dialami siswa dalam menyelesaikan soal-soal materi SPLDV adalah kesulitan dalam menggunakan sifat-sifat pertambahan dan perkalian pada persamaan, kesulitan menentukan lambang-lambang yang membentuk SPLDV, kesulitan menentukan hasil akhir, dan kesulitan dalam melakukan operasi pada bilangan. Faktor yang menyebabkan kesulitan-kesulitan tersebut adalah terburu-buru dalam menjawab soal, kurang teliti, lupa rumus, tidak memahami soal, dan salah mengoperasikan. Berdasarkan hasil analisis, nilai rata-rata persentase dari keseluruhan soal yang diberikan bahwa siswa tergolong rendah.

Kata kunci: Kesulitan siswa, konsep matematika, sistem persamaan linier dua variabel

Dikirim: 21 Januari 2020; Diterima: 15 Maret 2020; Dipublikasikan: 30 September 2020

Cara sitasi: Paujiah, S. R., \& Zanthy, L. S. (2020). Kesulitan siswa smp kelas viii dalam menyelesaikan soal sistem persamaan linier dua variabel (SPLDV). Teorema: Teori dan Riset Matematika, 5(2), 280-284. 


\section{PENDAHULUAN}

Matematika itu penting bagi kehidupan sehari-hari. Menurut Susanto (2015), matematika merupakan ilmu yang memiliki peran penting bagi kemajuan peradaban manusia. Matematika sebagai salah satu disiplin ilmu memiliki peranan yang penting dalam mengembangkan kemampuan berpikir peserta didik (Zakiah, 2016). Dengan mempelajari matematika seseorang terbiasa berpikir secara sistematis, ilmiah, menggunakan logika, kritis, serta dapat meningkatkan daya kreativitasnya. Matematika dapat ditinjau dari segala sudut, dan matematika itu sendiri bisa memasuki seluruh segi kehidupan manusia, dari yang paling sederhana sampai kepada yang paling kompleks.

Menurut Sariningsih \& Purwasih (Isnaeni et al., 2018), pendidikan matematika dapat membantu serta mendorong masyarakat untuk selalu maju tentang ilmu pengetahuan, terbukti dengan adanya banyak hasil perkembangan di bidang IPTEK yang semakin canggih dan modern. Oleh sebab itu, peserta didik sebaiknya mempelajari matematika sedini mungkin untuk membekali mereka.

Menurut Ranti (2015), mengungkapkan "mathematics as a human activity", yang maksudnya dalam kegiatan hidupnya setiap orang akan terlibat dalam matematika, baik dalam bentuk sederhana dan bersifat rutin, dan mungkin dalam bentuknya yang sangat kompleks. Menurut Susanto (2015), matematika merupakan salah satu bidang studi yang ada pada semua jenjang pendidikan, mulai dari tingkat sekolah dasar hingga perguruan tinggi. Pada sumber yang sama, tertera bahwa bidang studi matematika merupakan bidang studi yang berguna dan membantu dalam menyelesaikan berbagai masalah dalam kehidupan sehari-hari berhubungan dengan hitung menghitung atau yang berkaitan dengan angka-angka berbagai masalah, yang memerlukan suatu keterampilan dan kemampuan untuk memecahkannya.

Sesuai Permendikbud Nomor 22 Tahun 2016, terdapat salah satu standar kompetensi siswa SMP yaitu memahami Sistem Persamaan Linier Dua Variabel (SPLDV) dan menggunakannya dalam pemecahan masalah. Sehingga dapat disimpulkan bahwa agar siswa mampu memahami SPLDV dan menggunakannya dalam pemecahan masalah, siswa harus paham tentang topik PLDV.

Penelitian yang dilakukan oleh Mubarok \& Fitriani (2020) menyimpulkan bahwa kemampuan menganalisis pada materi SPLDV masih tergolong rendah. Hal ini dilihat dari banyaknya siswa yang mengalami kesulitan dalam menyelesaikan soal cerita yang berkaitan dengan SPLDV. Pencapaian jawaban siswa cukup bervariasi, dimulai dari kurang memahami soal, kendala dalam mengubah soal cerita ke dalam model matematika, berorientasi pada rumus, tidak memahami konsep, tidak menemukan cara yang tepat. Sehingga beberapa siswa tidak dapat menyelesaikan soal yang diberikan dengan cara yang tepat.

Hasil wawancara awal yang dilakukan dengan guru bidang studi matematika di salah satu SMP di kabupaten Cianjur, diketahui bahwa kesulitan siswa dalam menyelesaikan soal pada materi SPLDV adalah siswa kesulitan dalam memahami materi serta kesulitan memahami konsep matematika yang terdapat pada materi tersebut. Berdasarkan uraian di atas, peneliti tergerak untuk melakukan penelitian dan menganalisis kesulitan siswa SMP kelas VIII dalam menyelesaikan soal SPLD untuk mengetahui kesulitan-kesulitan yang dialami siswa dalam menyelesaikan soal SPLDV. Penelitian ini juga merupakan studi pendahuluan bagi penulis untuk melaksanakan penelitian selanjutnya.

\section{METODE PENELITIAN}

Penelitian ini menggunakan metode penelitian deskriptif yang bertujuan untuk mengetahui kesullitan siswa SMP di salah satu sekolah di Kabupaten Cianjur dalam menyelesaikan soal SPLDV dengan subjek penelitian sebanyak 13 orang siswa kelas VIII. Instrumen yang digunakan adalah soal uraian yang terdiri dari 5 butir soal dan dilakukan wawancara kepada beberapa siswa. Selanjutnya, hasil tes tersebut kami analisis sesuai dengan indikator yang telah dibuat. Selain menggunakan soal uraian, peneliti juga melakukan wawancara terhadap beberapa siswa. 
Indikator pembelajaran yang digunakan pada penelitian adalah sebagai berikut:

1) Menjelaskan koefisien, variabel, kostanta, dan suku.

2) Menjelaskan perbedaan SPLDV dan PLDV.

3) Menjelaskan SPLDV dengan metode substitusi.

4) Menjelaskan SPLDV dengan metode eliminasi.

5) Menjelaskan SPLDV dengan metode gabungan.

Penskoran terhadap jawaban siswa menggunakan rubrik penilaian dari Susilawati (2014) disajikan pada Tabel 1.

Tabel 1. Kriteria penilaian

\begin{tabular}{cl}
\hline Skor & \\
\hline 5 & Jawaban sesuai, benar, dan lengkap \\
4 & Jawaban benar namun kurang lengkap \\
3 & Sebagian jawaban benar namun memuat hanya satu atau lebih kesalahan pada saat langkah- \\
2 & Jangkah perhitungan \\
1 & Jawaban tidak lengkap \\
\hline
\end{tabular}

Kategori pencapaian pada penelitian ini menggunakan kategori pencapaian menurut Maya (2011) yang disajikan dalam Tabel 2.

Tabel 2. Kategori pencapaian

\begin{tabular}{cc}
\hline Kategori & Pencapaian \\
\hline Tinggi & $>70 \%$ \\
Sedang & $55 \% \geq 70 \%$ \\
Rendah & $\leq 55 \%$ \\
\hline
\end{tabular}

\section{HASIL DAN PEMBAHASAN}

Data hasil dari jawaban siswa pada soal uraian dikumpulkan, lalu dilakukan analisis untuk memperoleh suatu gambaran atau kesimpulan. Dari hasil analisis tes instrumen yang sudah dilakukan terhadap 13 orang siswa SMP kelas VIII dengan berupa 5 butir soal uraian, maka kesimpulannya adalah data yang didapat lalu diasumsikan berdasarkan acuan pedoman penskoran (Tabel 1) dari analisis jawaban siswa.

Hasil dari penskoran pada materi SPLDV dapat dlihat pada Tabel 3.

Tabel 3. Deskripsi skor tiap indikator soal

\begin{tabular}{cccccc}
\hline No. Soal & N & Minimum & Maksimum & Rata-rata & Persentase \\
\hline 1 & 13 & 1 & 5 & 2,15 & 43 \\
2 & 13 & 1 & 5 & 2,31 & 46,2 \\
3 & 13 & 1 & 5 & 2,46 & 49,2 \\
4 & 13 & 1 & 5 & 2,46 & 49,2 \\
5 & 13 & 1 & 5 & 2,15 & 43 \\
\hline
\end{tabular}

Rata-rata persentase pada soal nomor 1 adalah $43 \%$, berarti kebanyakan siswa tidak mampu menyelesaikan soal dengan benar. Pada soal nomor 2 dengan persentase 46,2\% sebagian siswa mampu menjawab soal dengan benar hanya saja jawaban yang mereka uraikan masih kurang lengkap. Pada soal nomor 3 dengan persentase 49,2\% sebagian siswa sudah mampu melakukan perhitungan dengan aturan tertentu. Pada soal nomor 4 dengan persentase $49,2 \%$ sebagian siswa mampu menyelesaikan soal dengan aturan perhitungan yang berbeda dengan aturan perhitungan pada soal sebelumnya. Soal nomor 5 memiliki persentase $43 \%$ sebagian besar siswa kesulitan dalam menyelesaikan soal cerita. Selanjutnya, rata-rata persentase dari keseluruhan soal adalah $46,12 \%$.

Berdasarkan hasil wawancara yang dilakukan terhadap 3 orang dari 13 orang siswa yang dijadikan subjek dalam penelitian ini, diketahui penyebab siswa tidak bisa menjawab soal dengan 
benar adalah terburu-buru dalam mengisi jawban, lupa rumus, tidak teliti, kurang memahami soal, dan salah mengoperasikan.

Persentase rata-rata dari keseluruhan soal tes yang diberikan adalah $46,12 \%$, ini menunjukkan kemampuan matematika siswa kelas VIII di salah satu SMP di kabupaten Cianjur tergolong rendah. Hal ini dikarenakan faktor siswa yang mudah menyerah dalam menghadapi permasalahan yang ada pada soal matematika, terburu-buru dalam menyelesaikan soal, lupa rumus, tidak teliti, dan kurang memahami soal. Meskipun demikian, ada siswa yang mampu menyelesaikan soal dengan cara dikira-kira.

Kesulitan yang dialami siswa ditandai dengan adanya kesalahan-kesalahan siswa dalam menjawab soal yang diberikan. Kesalahan-kesalahan yang dimaksud adalah kesalahan-kesalahan dalam menggunakan sifat-sifat pertambahan dan perkalian pada persamaan, kesalahan dalam melakukan operasi pada bilangan, kesalahan dalam menentukan hasil akhir, dan kesalahan dalam menempatkan lambang-lambang yang membentuk SPLDV.

1. Indikator menyelesaikan masalah SPLDV dengan metode gabungan

Pada suatu hari Ikbal dan Roni pergi ke sebuah toko alat tulis. Jumlah uang yang dimiliki oleh Ikbal adalah Rp. 100.000,00 dan Roni Rp. 50.000,00. Ikbal membeli 2 buku dan 3 pensil 2B dengan harga Rp. 80.000,00,sedangkan Roni membeli 1 buku dan 1 pensil 2B dengan harga Rp. 35.000,00. Citra mempunyai uang sebesar Rp. 165.000,00 dan ingin membeli buku dan pensil $2 \mathrm{~B}$ dengan jumlah terbanyak, tetapi barang yang tersisa di toko alat tulis tersebut adalah 4 buku dan 6 pensil 2B. Berapakah sisa uang Citra jika ia membeli semua barang yang tersisa di toko tersebut?.

Salah satu kesalahan siswa dalam menjawab soal nomor 5 ditampilkan pada Gambar 1.

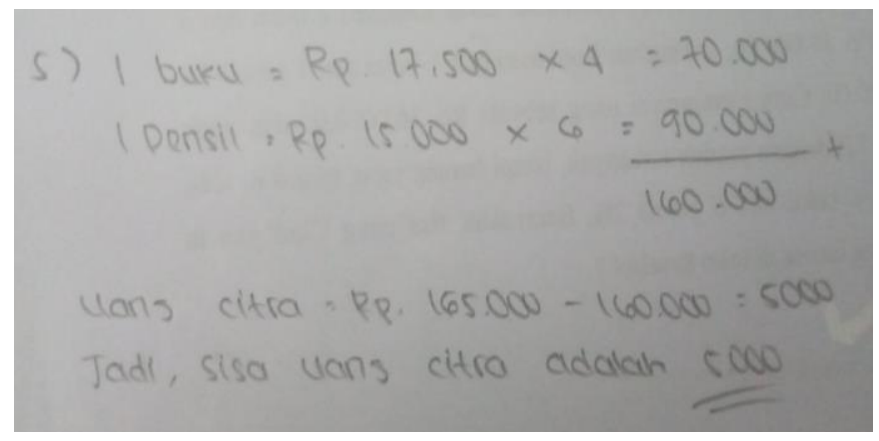

Gambar 1. Jawaban siswa pada soal nomor 5

Berdasarkan Gambar 1 terlihat jawaban akhir siswa hasilnya benar, akan tetapi kesalahan dari jawaban ini terletak pada langkah-langkah yang diuraikan siswa dalam menjawab soal. Dari jawaban di atas siswa hanya mengira-ngira hasil akhir saja dan tidak memahami langkah-langkah atau metode penyelesaian dari soal yang diberikan.

\section{KESIMPULAN}

Berdasarkan uraian dari hasil penelitian dan pembahasan, maka dapat disimpulkan bahwa sebagian besar siswa kelas VIII di salah satu SMP swasta di kabupaten Cianjur masih mengalami kesulitan dalam menyelesaikan soal-soal pada materi Sistem Persamaan Linier Dua Variabel (SPLDV). Kesulitan yang dialami siswa ditandai dengan adanya kesalahan-kesalahan dalam menjawab soal yang berkaitan dengan SPLDV. Kesalahan-kesalahan yang dimaksud adalah kesalahan dalam menggunakan sifat-sifat pertambahan dan perkalian pada persamaan, kesalahan dalam melakukan operasi pada bilangan, kesalahan dalam menentukan hasil akhir, dan kesalahan dalam menempatkan lambang-lambang yang membentuk SPLDV. Adapun faktor penyebabnya adalah siswa terburu-buru dalam menjawab soal, kurang teliti, tidak memahami soal, lupa rumus, dan salah mengoperasikan. 


\section{REKOMENDASI}

Beberapa hal dapat direkomendasikan berdasarkan hasil penelitian ini yaitu bahwa pembelajaran matematika pada materi SPLDV harus disampaikan secara rinci, karena sebagian besar siswa masih sangat kesulitan dalam menyelesaikan soal pada materi SPLDV. Hal ini ditunjukkan dengan banyaknya kesalahan yang dilakukan siswa dalam proses penyelesaian soal yang diberikan. Diantara perbaikan yang dapat dilakukan dengan menerapkan model dan pendekatan pembelajaran yang sesuai dengan materi yang akan disampaikan. Untuk penelitian berikutnya diharapkan mengadakan penelitian sejenis lebih lanjut dengan mengambil wilayah penelitian yang lebih luas, sampel yang lebih banyak dan menggunakan rancangan penelitian yang lebih kompleks, serta melakukan penelitian ditingkat pendidikan yang lebih tinggi, seperti pada siswa SMA. Sehingga dapat ditemukan hasil yang lebih optimal dan bisa digeneralisasikan pada wilayah yang lebih luas.

\section{UCAPAN TERIMA KASIH}

Kami mengucapkan terima kasih kepada Yayasan Pendidikan Islam Al-I'ttihadiah Cianjur, Kepala MTs Al-I'ttihadiah Cianjur, siswa dan siswi kelas VIII MTs Al-l'ttihadiah Cianjur yang telah memberikan kerjasama yang baik dalam dalam penelitian ini, sehingga penelitian ini dapat dilaksanakan dengan baik.

\section{DAFTAR PUSTAKA}

Isnaeni, S., Fajriyah, L., Rizky, E. S., Purwasih, R., \& Hidayat, W. (2018). Analisis kemampuan penalaran matematis dan kemandirian belajar siswa smp pada materi persamaan garis lurus. Jurnal of Medives. 2(1), 107-115.

Maya, R. (2011). Pengaruh pembelajaran dengan medote moore termodifikasi terhadap pencapaian kemampuan pemahaman dan pembuktian matematik mahasiswa. Disertasi UPI: Tidak diterbitkan.

Mubarok, R., \& Fitriani, N. (2020). Analisis pencapaian siswa smp dalam menyelesaikan soal persamaan linear dua variabel di smpn 1 campaka mulya-cianjur. JPMI-Jurnal Pembelajaran Matematika Inovatif, 3(5), 507-516.

Permendikbud Nomor 22 Tahun 2016 tentang Standar Proses Pendidikan Dasar dan Menengah. Online document.

Ranti, M. G. (2015). Meningkatkan komunikasi matematis siswa menggunakan strategi writing to learn pada siswa smp. Math Didactic: Jurnal Pendidikan Matematika, 1(2).

Susanto, A. (2015). Teori belajar \& pembelajaran di sekolah dasar. Jakarta: Prenadamedia Grup.

Susilawati. (2014). Pengaruh layanan guru dan kepemimpinan transformasional kepala sekolah terhadap mutu sekolah dasar di kota cilegon. Universitas Pendidikan Indonesia. [Onlline]. Tersedia: http://repository.upi.edu. [27 November 2019].

Zakiah, N. E. (2016). Meningkatkan kemampuan metakognitif siswa melalui pembelajaran dengan pendekatan open-ended. Teorema: Teori dan Riset Matematika, 1(1). 